\title{
Differential Number of CD34+, CD133+ AND CD34+/CD133+ Cells in Peripheral Blood of Patients with Congestive HEART FAILURE
}

\author{
M. Fritzenwanger ${ }^{1}$, F. Lorenz ${ }^{2}$, C. Jung ${ }^{1}$, M. Fabris ${ }^{2}$, H. Thude ${ }^{2}$, D. Barz ${ }^{2}$, H. R. Figulla ${ }^{1}$ \\ ${ }^{1}$ Department of Internal Medicine I, ${ }^{2}$ Institute for Transfusion Medicine, Friedrich-Schiller-University, Jena, Germany
}

\begin{abstract}
Background: Endothelial progenitor cells (EPC) which are characterised by the simulateous expression of CD34, CD133 and vascular endothelial growth receptor 2 (VEGF 2) are involved in the pathophysiology of congestive heart failure $(\mathrm{CHF})$ and their number and function is reduced in CHF. But so far our knowledge about the number of circulating hematopoietic stem/ progenitor cells (CPC) expressing the early hematopoietic marker CD133 and CD34 in CHF is spares and therefore we determined their number and correlated them with New York Heart Association (NYHA) functional class.

Methods: CD34 and CD133 surface expression was quantified by flow cytometry in the peripheral venous blood of 41 healthy adults and 101 patients with various degrees of CHF.

Results: CD34+, CD133+ and CD34+/CD133+ cells correlated inversely with age. Both the number of CD34+ and of CD34+/CD133+ cells inversely correlated with NYHA functional class. The number of CD133+ cells was not affected by NYHA class. Furthermore the number of CD133+ cells did not differ between control and $\mathrm{CHF}$ patients.

Conclusion: In CHF the release of CD34+, CD133+ and $\mathrm{CD} 34+/ \mathrm{CD} 133+$ cells from the bone marrow seems to be regulated differently. Modulating the releasing process in $\mathrm{CHF}$ may be a tool in CHF treatment.

Key words: CD34, CD133, congestive heart failure, progenitor cell
\end{abstract}

\section{INTRODUCTION}

In the last decades our understanding of the pathophysiology and treatment of heart failure has increased substantially, especially the complex interaction between the heart, peripheral circulation, humoral and cellular system has been illuminated [1].

In the blood immature cells with the capacity to differentiate into mature endothelial cells were detected and are therefore called EPC. EPCs are identified by the simultaneous expression of the characteristic surfacemarkers CD34, CD133 and VEGF-R2 and originate from the bone marrow. EPCs are involved in endogenous endothelial repair, myocardial ischemia, my- ocardial infarction, limb ischemia, wound healing and atherosclerosis [2]. Patients with heart failure show endothelial dysfunction, diminished $\mathrm{NO}$ availability and increased endothelial apoptosis [3].

There are many experimental and clinical data which show that in CHF the number of EPC is diminished and their function is impaired [4]. But so far there are only few reports in CHF dealing with the number and function of EPC precursors named circulating progenitor cells (CPC) mobilized from the bone marrow. CPC express the surfacemarkers CD34 and CD133 and are probably the most primitive progenitor cells in the circulation. CD34 is found on hematopoietic stem cells and on mature endothelial cells. CD133 is expressed on hematopoietic progenitor cells but is not found on mature endothelial cells. CPC are primitive bone marrow cells and can proliferate, migrate, differentiate into various matures cell types $[5,6]$ and are proangiogenic [7].

Our study examined the number of CD34+, CD133+ and CD34+/CD133+ cells in the peripheral blood of healthy adults and in patients with various NYHA functional classes.

\section{Materials AND Methods}

\section{PATIENTS}

We enroled 101 patients with New York Heart Association (NYHA) functional class I-IV (Table 1) of our hospital. The diagnosis of heart failure was confirmed by clinical findings and non-invasive assessment of cardiac function. Left ventricular ejection fraction (LVEF) was determined by echocardiography. As a control we used 41 healthy male blood donors $(32 \pm 7$ years). The study was approved by the local Ethics committee and written informed consent was obtained from patients.

\section{Blood Collection}

Blood collection was done on the day of admission. All patients were supine, a 21-gauge needle was inserted into an antecubital vein. A $9 \mathrm{ml}$ sample of whole blood was obtained in a EDTA plasic container (Sarstedt, Germany). 
Table 1. Characteristics of patients.

\begin{tabular}{|c|c|c|c|c|}
\hline Variables & $\begin{array}{c}\text { NYHA class I } \\
\mathrm{N}=16\end{array}$ & $\begin{array}{c}\text { NYHA class II } \\
\mathrm{N}=25\end{array}$ & $\begin{array}{c}\text { NYHA class III } \\
\mathrm{N}=30\end{array}$ & $\begin{array}{c}\text { NYHA class IV } \\
\mathrm{N}=30\end{array}$ \\
\hline Age, y & $66.3 \pm 8.1$ & $66.9 \pm 8.1$ & $68.5 \pm 7.6$ & $68.7 \pm 10.6$ \\
\hline $\mathrm{BMI}, \mathrm{kg} / \mathrm{m}^{2}$ & $28.8 \pm 4.5$ & $29.0 \pm 3.5$ & $27.3 \pm 4.4$ & $29.3 \pm 6.2$ \\
\hline WBC, $10^{3} / \mathrm{mm}^{3}$ & $7.1 \pm 1.9$ & $8.2 \pm 1.8$ & $8.1 \pm 2.2$ & $10.6 \pm 4.1$ \\
\hline LVEF, $\%$ & $51.1 \pm 14.8$ & $37.0 \pm 12.6$ & $31.1 \pm 9.8$ & $33.8 \pm 13.6$ \\
\hline LVDd, mm & $58.1 \pm 9.8$ & $64.0 \pm 13.0$ & $62.6 \pm 10.2$ & $59.6 \pm 6.8$ \\
\hline VO2 peak, $\mathrm{ml} \mathrm{x} \mathrm{kg}^{-1} \times \mathrm{min}^{-1}$ & $22.3 \pm 10.4$ & $19.0 \pm 4.3$ & $17.9 \pm 4.8$ & $12.0 \pm 2.1$ \\
\hline $\mathrm{BNP}, \mathrm{pmol} / \mathrm{l}$ & $32.4 \pm 33.2$ & $85.7 \pm 83.5$ & $222 \pm 204$ & $474 \pm 461$ \\
\hline $\begin{array}{l}\text { Underlying heart disease, } \mathrm{n} \\
\text { - DCM } \\
\text { - Hypertension } \\
\text { - CAD } \\
\text { - Myocarditis } \\
\text { - others }\end{array}$ & $\begin{array}{l}3(19 \%) \\
6(38 \%) \\
5(31 \%) \\
1(6 \%) \\
1(6 \%)\end{array}$ & $\begin{array}{l}9(36 \%) \\
4(16 \%) \\
10(40 \%) \\
0(0 \%) \\
2(8 \%)\end{array}$ & $\begin{array}{c}2(7 \%) \\
8(27 \%) \\
16(53 \%) \\
0(0 \%) \\
4(13 \%)\end{array}$ & $\begin{array}{c}3(10 \%) \\
0(0 \%) \\
20(67 \%) \\
0(0 \%) \\
7(23 \%)\end{array}$ \\
\hline Diabetes mellitus, $\mathrm{n}$ & $5(31 \%)$ & $12(48 \%)$ & $13(43 \%)$ & $11(37 \%)$ \\
\hline Smoking, $\mathrm{n}$ & $4(25 \%)$ & $4(16 \%)$ & $1(3 \%)$ & $3(10 \%)$ \\
\hline Statin, $\mathrm{n}$ & $7(44 \%)$ & $10(40 \%)$ & $16(53 \%)$ & $18(60 \%)$ \\
\hline
\end{tabular}

Values are mean \pm SD or number of patients. BMI, body mass index; WBC, white blood cells; LVEF, left ventricular ejection fraction; BNP, B-type natriuretic peptide; DCM, dilatative cardiomyopathy; CAD, coronary artery disease; NYHA, New York Heart Association.

\section{Flow CyTOMETRIC ANALysis}

The number of CD34+, CD133+ and CD34+/CD133+ mononuclear cells in the peripheral blood was determined by flow cytometry (FACS Calibur, Becton Dickinson, Heidelberg, Germany). Briefly, white blood cells were stained with fluorescent isothiocyanate (FITC)conjugated CD34 antibody (clone: 581, Becton Dickinson/Pharmigen, Heidelberg, Germany) and a phycoerythrin (PE)-conjugated CD133/2 antibody (clone: 293C3, Miltenyi biotec, Bergisch Gladbach, Germany). For negative controls, cells were stained with FITCand PE-conjugated mouse IgG1 (Becton Dickinson/Pharmingen, Heidelberg, Germany) and mouse IgG2b (Becton Dickinson/Pharmingen, Heidelberg, Germany).

\section{STATISTICAL ANALYSis}

Data are expressed as mean \pm SD. Data were analyzed by nonparametric tests to avoid assumptions about the distribution of the measured variables. Bivariant regression analysis is shown in graphical forms and correlations were examined by Pearson correlation test. A P-value of $<0.05$ was considered significant. All statistical analyses were performed with WinSTAT.

\section{RESULTS}

Circulating CD133+, CD34+ and CD34/CD133+ cells correlate with age
In $\mathrm{CHF}$ we found a negative correlation of the number of CD34+, CD133+ and CD34/133+ cells with age $(\mathrm{CD} 133+\mathrm{y}=1234-123 \mathrm{x}, \mathrm{r}=0.18, \mathrm{P}=0.037, \mathrm{n}=$ 101; CD34+: $\mathrm{y}=1643-12 \mathrm{x}, \mathrm{r}=0.17, \mathrm{P}=0.048, \mathrm{n}=$ 101; CD34/CD133+: $\mathrm{y}=1325-12 \mathrm{x}, \mathrm{r}=0.29, \mathrm{P}=$ $0.001, \mathrm{n}=101)$. In $\mathrm{CHF}$ number of CD133+, CD34+ and CD34+/133+ cells decreases with age (Fig. 1).

Circulating CD34+, CD133+ and CD34/CD133+ cells and NYHA functional class

As shown in Figure 2 we found a small decrease of the number of CD133+ cells in CAD in NYHA functional class I and II and an increase of these cells in NYHA III and IV compared to control. In non CAD patients only in NYHA III we found a decrease of CD133+ cells. Furthermore also the number of peripheral CD133+ cells was not affected significantly by NYHA functional class.

Both numbers of CD34+ and CD34+/CD133+ cells were lower in patients than in the control group (CD34+ in controls $2824 \pm 1904$ per $\mathrm{ml}$ and CD34+/CD133+ in controls $1164 \pm 482)$. Furthermore the number of CD34+ and CD34+/CD133+ cells decreased with increasing NYHA functional class. Except in NYHA I for the number of CD34/CD133+ cells we did not find a difference between the number of CD133+, CD34+ and CD34+/CD133+ cells in the CAD or not CAD group indicating that the cause of $\mathrm{CHF}$ did not influence peripheral progenitor cell number.

As shown in Table 2 a correlation analysis revealed no correlation between NYHA functional class and 

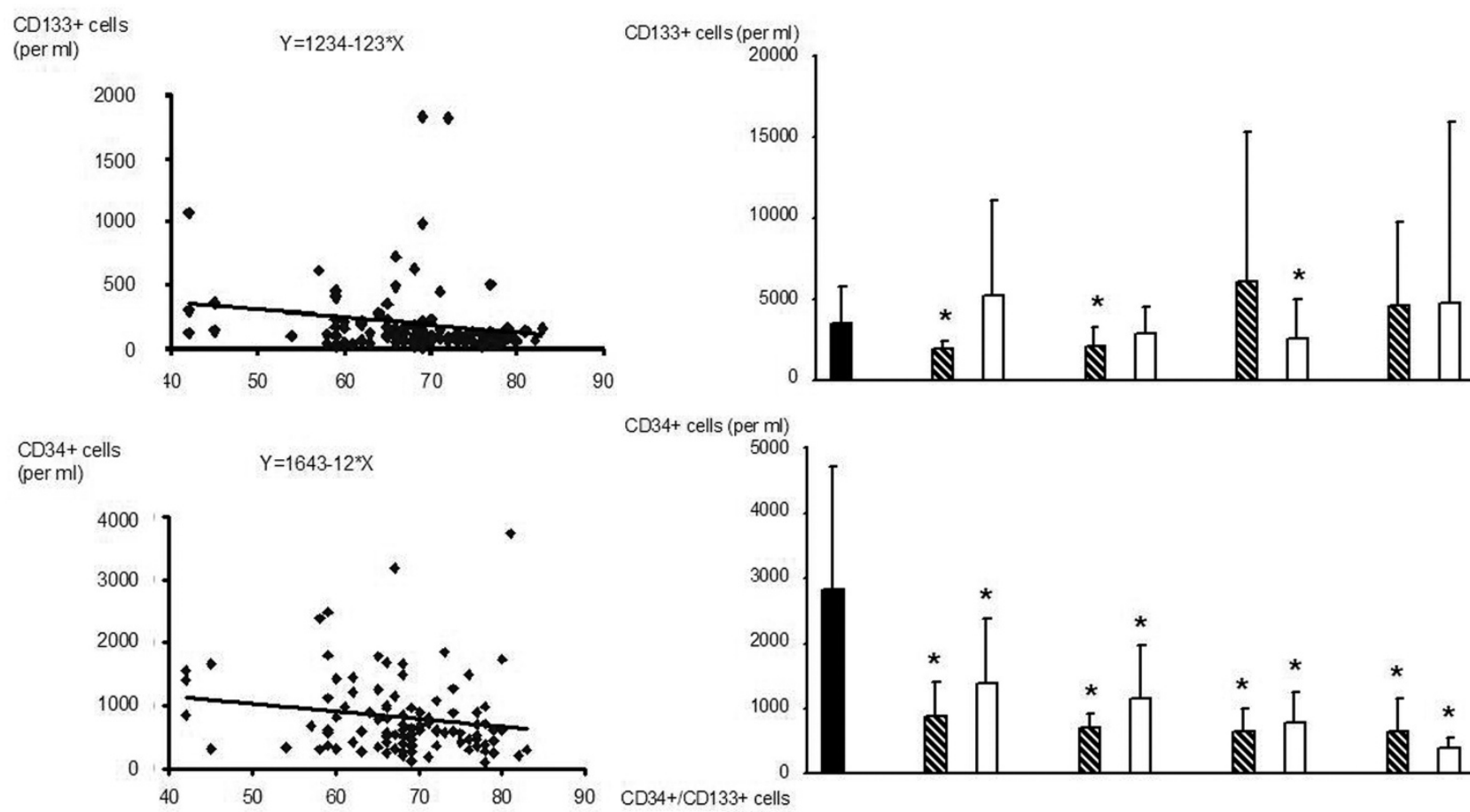

CD34+ cells (per ml)

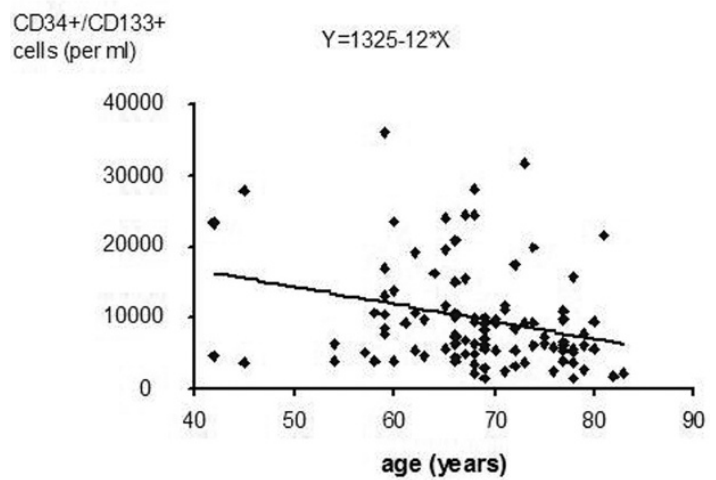

$\mathrm{CD} 34+/ \mathrm{CD} 133+$ cells
(per ml)

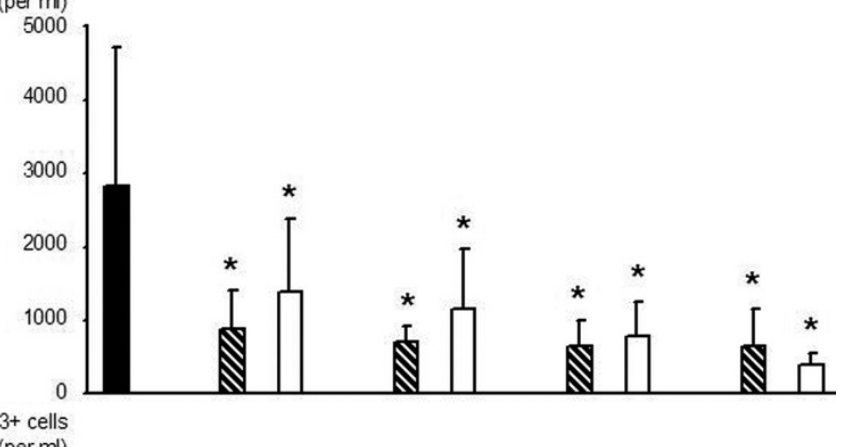

Fig. 1. Correlation of $\mathrm{CD} 133+, \mathrm{CD} 34+$ and CD34+ / CD133+ cells (CD133+: $\mathrm{r}=0.18, \mathrm{P}=$ $0.037, \mathrm{n}=101 ; \mathrm{CD} 34+: \mathrm{r}=0.17, \mathrm{P}=0.048, \mathrm{n}=101$ CD34/CD133+: $\mathrm{r}=0.29, \mathrm{P}=0.001, \mathrm{n}=101)$ in $\mathrm{pa}-$ tients with various degrees of $\mathrm{CHF}$ and age.

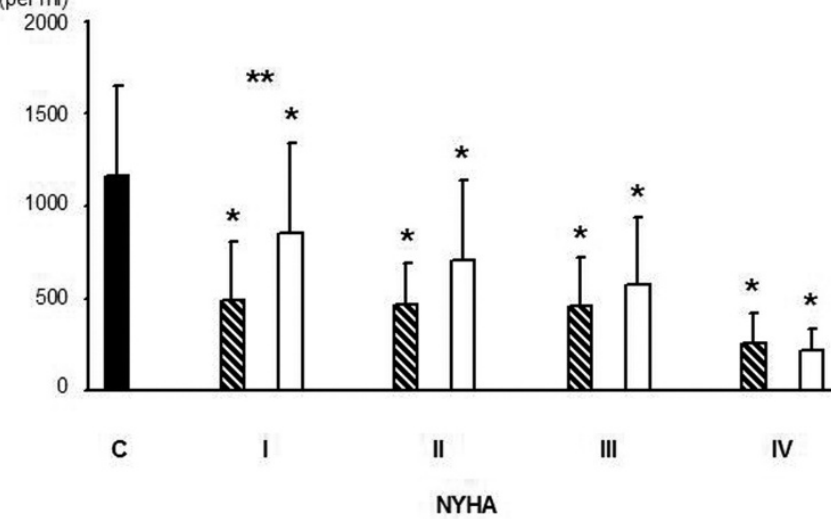

Fig. 2. Number of peripheral CD133+, CD $34+$ and $\mathrm{CD} 34+/$ CD133+ cells in controls (C) and patients with various NYHA functional classes. ${ }^{*} \mathrm{p}<0.05$ compared to control. ${ }^{* *} \mathrm{p}<0.05$ CAD vs. no CAD. Black bars: control. Striped bars: CAD. White bars: no CAD. CAD: coronary artery disease.

Table 2. Association between NYHA functional class in CAD and no CAD patients and number of CD133+, CD34+ and CD34+/CD133+ cells.

\begin{tabular}{llll}
\hline NYHA functional class & $\begin{array}{l}\text { Number of CD133+ cells } \\
\mathrm{r}(\mathrm{p} \text { value })\end{array}$ & $\begin{array}{l}\text { Number of CD34+ cells } \\
\mathrm{r}(\mathrm{p} \text { value })\end{array}$ & $\begin{array}{l}\text { Number of CD34+/133+ cells } \\
\mathrm{r}(\mathrm{p} \text { value })\end{array}$ \\
\hline CAD & $0.17(0.11)$ & $0.14(0.16)$ & $0.36(0.006)^{*}$ \\
no CAD & $0.04(0.39)$ & $0.47(0.0003)^{*}$ & $0.49(9.86 \mathrm{E}-05)^{*}$ \\
\hline
\end{tabular}

CAD: coronary artery disease. ${ }^{*} \mathrm{p}<0.05$.

the number of CD133+ cells. In CAD patients only the number of CD34+/CD133+ cells showed a correlation with NYHA class $(Y=642-86 \mathrm{X}, \mathrm{r}=0.36, \mathrm{p}=$ $0.006)$ whereas in patients without CAD either the number of CD34+ cells $(\mathrm{Y}=1786-341 \mathrm{X}, \mathrm{r}=0.47, \mathrm{p}$ $=0.0003)$ and the number of CD34+/CD133+ cells $(\mathrm{Y}=1096-200 \mathrm{X}, \mathrm{r}=0.49, \mathrm{p}=9.86 \mathrm{E}-05)$ correlated with NYHA functional class. 


\section{DISCUSSION}

The first result of our study is that in CHF the peripheral number of CD34+, CD133+ and CD34+/ CD133+ cells decreases with increasing age. This finding is in good agreement with a study published by Shaffer et al. [8] which found that the number of CD34+, CD133+ and CD34+/CD133+ cells is elevated in younger healthy compared to older individuals. A similar result was reported by Scheubel et al. [9]. This group described a decreasing number of CD34+/CD133+ cells with age in patients before bypass surgery and made decreasing VEGF concentrations with age responsible. Because $\mathrm{CHF}$ alone does not influence VEGF concentrations significantly ageinduced VEGF decrease may also be responsible in patients with heart failure $[10,11]$.

The second important result of our study is the fact that correlation analysis showed that the number of CD34+ and CD34+/CD133+ cells decreased with increasing NYHA functional class, whereas the number of CD133+ cells was unaffected by NYHA functional class. The first study which described a regulation of the number of CD34+ cells was published by Valgimigli et al. [12]. Valgimigli found a decrease of CD34+ cells with increasing NYHA functional class. The fact that in NYHA I and II the number of CD34+ cells was higher compared to control could not be reproduced in our study. This may be due to the fact that our control group was much younger than the study group whereas Vaglimigli examined an age-matched control group. Our study also confirmes the results of Theiss et al. [11] which described higher numbers of CD34+ and CD34+/CD133+ cells in dilated cardiomyopathy (DCM) than in coronary artery disease (CAD). Different to this study we examined the number of CD34+ and CD34+/CD133+ cells for every NYHA functional class. Also in our study there was a tendency to a higher number of CD34+ or CD34+/CD133+ cells in DCM in NYHA functional class I-III and a lower number in NYHA IV without reaching a significant difference between CAD and no CAD patients. That we did not see a significant difference between CAD and no CAD patients may be the result of the small number of patients in the subgroups and large standard deviations. Whether aetiology of CHF involves EPC number is still not known because there is also a study by Michowitz et al. showing that aetiology did not influence EPC number measured by EPC-colony-forming units [13]. Furthermore we did not only show that with increasing NYHA functional class the number of CD34+ and CD34+/CD133+ decreased but that there is a negative correlation between NYHA functional class and the number of CD34+/CD133+ cells in CAD patients and the number of CD34+ and CD34+/CD133+ cells in no CAD patients.

The third important result is that the number of CD133+ cells is only affected by age and not by heart failure. This is interesting because CD133 marks the most primitive circulating progenitor cells [14]. The function of the early haematopoietic stem cells marker CD133 is not known. Using CD133 expression to define a very early subset of progenitor cells Peichev et al. [15] isolated a subpopulation which was able to differentiate into mature endothelial cells. Furthermore CD133+ cells of the bone marrow have been shown to have endothelial character and may contribute to neoangiogenesis [16].

Taking under consideration that Heeschen et al. [17] found no difference between the number of CD34+ and CD34+/CD133+ cells in the bone marrow in healthy controls and patients with ischemic cardiomyopathy we speculate that in $\mathrm{CHF}$ the release of CD34+, CD133+ and CD34+/CD133+ cells is differently affected by $\mathrm{CHF}$. The mechanism responsible for this different regulation of progenitor cell release is not explained so far. An increased tumor necrosis factor (TNF) $\alpha$ concentration which is found in CHF may be responsible [12]. An animal study suggested that TNF $\alpha$ might increase apoptosis of progenitor cells in the bone marrow of mice with ischemic heart failure [18]. So far neither the exact mechanism of differential regulation of different CPC subsets is not known nor the biological meaning of this observation. A recently published study by Geft et al. showed that not only the number of CD34+ cells are decreased by increasing NYHA functional class but in moderate to severe heart failure the number of irreversible apoptotic CD34+ cells were significantly increased [19].

\section{LiMITATIONS OF THE STUDY}

There are some limitations of our study. One is that we have a significant younger contol group. But the fact that we found different numbers of $\mathrm{CD} 34+$, CD133+ and CD34/CD133+ cells in CHF is independent of a control group. We can not exclude that in moderate $\mathrm{CHF}$ the number of $\mathrm{CD} 34+, \mathrm{CD} 133+$ and CD34/CD133+ cells are higher than in an aged matched control group as shown by Valgimigli et al. [12] but the fact that the number of these cells is regulated in a different manner in CHF is not affected.

A further limitation is that statin treatment is higher in NYHA III and IV than in NYHA I and II. Because statines cause mobilisation of EPC [16] the observed decreased number of CD34+ and CD133+ cells should be much lower without statin treatment and therefore the measured effect is under- than overestimated. Because smoking also reduces EPC number the here presented differential number of CD34+, CD133+ and CD34/CD133+ cells is underestimated in lower NYHA classes because of the higher number of smokers in NYHA I and II compared to NYHA III and IV.

We also did not measure the concentration of known cytokines influencing endothelial progenitor cell number. However this was done by several studies measuring and correlating EPC number with the concentration of this cytokines $[11,12,13,20]$.

\section{Author Contributions}

Michael Fritzenwanger had full access to all the data in the study and takes responsibility for the integrity of the data and the accuracy of the data analysis.

Study concept and design:

Acquisition of data:

Analysis and interpretation of data:

Drafting of the manuscript:
MF, FL, HF

FL, MFA

MF, FL, CJ, HT

MF, FL, MFA,CJ, HT 
Critical revision of the manuscript: Statistical analysis:

CJ, HT, DB, HF MF

Obtained funding: HF

Administrative, technical, or material support:

Study supervision:

HT, DB, HF MF, HT, DB, HF

Michael Fritzenwanger: $\quad$ MF

Franziska Lorenz: $\quad$ FL

Christian Jung: CJ

Marlen Fabris: MFA

Hansjörg Thude: HT

Dagmar Barz: $\quad$ DB

Hans R. Figulla: HF

\section{REFERENCES}

1. McMurray JJ, Pfeffer MA. Heart failure. Lancet. 2005 May 28-Jun 3;365(9474):1877-89.

2. Khakoo AY, Finkel T. Endothelial progenitor cells. Annu Rev Med. 2005;56:79-101.

3. Agnoletti L, Curello S, Bachetti T, Malacarne F, Gaia G, Comini L, Volterrani M, Bonetti P, Parrinello G, Cadei M, Grigolato PG, Ferrari R. Serum from patients with severe heart failure downregulates eNOS and is proapoptotic: role of tumor necrosis factor-alpha. Circulation. 1999 Nov 9;100(19):1983-91.

4. Andreou I, Tousoulis D, Tentolouris C, Antoniades C, Stefanadis C. Potential role of endothelial progenitor cells in the pathophysiology of heart failure: clinical implications and perspectives. Atherosclerosis. 2006 Dec;189(2): 247-54. Epub 2006 Jul 24.

5. Luttun A, Carmeliet G, Carmeliet P. Vascular progenitors: from biology to treatment. Trends Cardiovasc Med. 2002 Feb;12(2):88-96.

6. Szmitko PE, Fedak PW, Weisel RD, Stewart DJ, Kutryk MJ, Verma S. Endothelial progenitor cells: new hope for a broken heart. Circulation. 2003 Jun 24;107(24):3093-100.

7. Prater DN, Case J, Ingram DA, Yoder MC. Working hypothesis to redefine endothelial progenitor cells. Leukemia 2007;21:1141-1149.

8. Shaffer RG, Greene S, Arshi A, Supple G, Bantly A, Moore JS, Mohler ER 3rd. Flow cytometric measurement of circulating endothelial cells: the effect of age and peripheral arterial disease on baseline levels of mature and progenitor populations. Cytometry B Clin Cytom. 2006 70:56-62.

9. Scheubel RJ, Zorn H, Silber RE, Kuss O, Morawietz H, Holtz J, Simm A. Age-dependent depression in circulating endothelial progenitor cells in patients undergoing coronary artery bypass grafting. J Am Coll Cardiol. 2003; 42(12):2073-80.

10. Nonaka-Sarukawa M, Yamamoto K, Aoki H, Nishimura Y, Tomizawa H, Ichida M, Eizawa T, Muroi K, Ikeda U, Shimada K. Circulating endothelial progenitor cells in congestive heart failure. Int J Cardiol. 2007;119(3):344-8. Epub 2006 Oct 27.

11. Theiss HD, David R, Engelmann MG, Barth A, Schotten K, Naebauer M, Reichart B, Steinbeck G, Franz WM. Circulation of $\mathrm{CD} 34+$ progenitor cell populations in patients with idiopathic dilated and ischaemic cardiomyopathy (DCM and ICM). Eur Heart J. 2007;28(10):1258-64. Epub 2007 Mar 29.
12. Valgimigli M, Rigolin GM, Fucili A, Porta MD, Soukhomovskaia O, Malagutti P, Bugli AM, Bragotti LZ, Francolini G, Mauro E, Castoldi G, Ferrari R. CD34+ and endothelial progenitor cells in patients with various degrees of congestive heart failure. Circulation. 2004;110(10): 1209-12. Epub 2004 Jul 12.

13. Michowitz Y, Goldstein E, Wexler D, Sheps D, Keren G, George J. Circulating endothelial progenitor cells and clinical outcome in patients with congestive heart failure. Heart. 2007;93(9):1046-50. Epub 2007 Feb 3.

14. Schatteman G. Are circulating CD133+ cells biomarkers of vascular disease? Arterioscler Thromb Vasc Biol. 2005; 25(2):270-1.

15. Peichev M, Naiyer AJ, Pereira D, Zhu Z, Lane WJ, Williams M, Oz MC, Hicklin DJ, Witte L, Moore MA, Rafii S. Expression of VEGFR-2 and AC133 by circulating human $\mathrm{CD} 34(+)$ cells identifies a population of functional endothelial precursors. Blood. 2000 Feb 1;95(3): 952-8.

16. Quirici N, Soligo D, Caneva L, Servida F, Bossolasco P, Deliliers GL. Differentiation and expansion of endothelial cells from human bone marrow CD133(+) cells. Br J Haematol. 2001 Oct;115(1):186-94.

17. Heeschen C, Lehmann R, Honold J, Assmus B, Aicher A, Walter DH, Martin H, Zeiher AM, Dimmeler S. Profoundly reduced neovascularization capacity of bone marrow mononuclear cells derived from patients with chronic ischemic heart disease. Circulation. 2004;109(13):1615-22. Epub 2004 Mar 22.

18. Iversen PO, Woldbaek PR, Tønnessen T, Christensen G. Decreased hematopoiesis in bone marrow of mice with congestive heart failure. Am J Physiol Regul Integr Comp Physiol. 2002;282(1):R166-72.

19. Geft D, Schwartzenberg S, Rogowsky O, Finkelstein A, Ablin J, Maysel-Auslender S, Wexler D, Keren G, George $\mathrm{J}$. Circulating apoptotic progenitor cells in patients with congestive heart failure. PLoS ONE. 2008 Sep 18;3(9): e3238.

20. Kissel CK, Lehmann R, Assmus B, Aicher A, Honold J, Fischer-Rasokat U, Heeschen C, Spyridopoulos I, Dimmeler S, Zeiher AM. Selective functional exhaustion of hematopoietic progenitor cells in the bone marrow of patients with postinfarction heart failure. J Am Coll Cardiol. 2007;49(24):2341-9.

Received: January 6, 2009 / Accepted: January 12, 2009

Address for correspondence:

Dr. med. Michael Fritzenwanger

Department of Internal Medicine I

Division of Cardiology

Friedrich-Schiller-University Jena

Erlanger Allee 101

07740 Jena

$\mathrm{Tel}+49-3641-9324528$

Fax +49-3641-9324102

E-mail: Michael.Fritzenwanger@med.uni-jena.de 